\title{
OPTIMALISASI PEMANFAATAN PEKARANGAN MELALUI PROGRAM RUMAH PANGAN LESTARI DI LINGKUNGAN PEJERUK KOTA MATARAM
}

\section{Optimization Of The Utilization Of House Yard Through The Rumah Pangan Lestari Program In Pejeruk Abiyan Village, Kota Mataram}

\section{Ketut Gede Wiryawan ${ }^{1 *}$, D. Andika Ristiawanna Rangga ${ }^{2}$, Abdul Faruk ${ }^{3}$, Ahmad $^{1}$, Alpini Aulia ${ }^{4}$, Abymanyu Putra A. ${ }^{5}$, Dani Syaiful Akbar ${ }^{6}$, Mita Rahmatullah7, Mutiara ${ }^{8}$, Ria Fitriani ${ }^{9}$, Siti Safinah ${ }^{10}$}

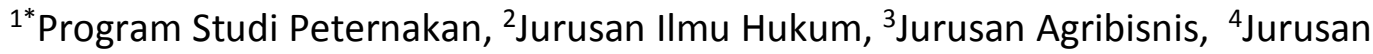
Agroekoteknologi, ${ }^{5} J u r u s a n$ Teknik Mesin, ${ }^{6} J u r u s a n$ Farmasi, 7 Jurusan Budidaya Perairan, ${ }^{8} \mathrm{Jurusan}$ Kehutanan, ${ }^{9} \mathrm{Jurusan}$ Agroekoteknologi, ${ }^{10} \mathrm{Jurusan}$ Teknik Pertanian,

Jalan Majapahit 62 Mataram 83125 Kota Mataram, Provinsi NTB.

*Alamat korespondensi: k_wiryawan@unram.ac.id

(Tanggal Submission: 14 Maret 2021, Tanggal Accepted : 17 April 2021)

\begin{abstract}
Keyword: Abstract :
Rumah Pertambahan jumlah penduduk dan perkembangan suatu kota berakibat pada Pangan terjadinya permasalahan keterbatasan lahan untuk kegiatan di bidang pertanian. Lestari, Kelurahan Pejeruk adalah salah satu kelurahan di Kecamatan Ampenan, Kota pemanfaatan Mataram yang wilayahnya sudah dipenuhi oleh rumah-rumah warga sehingga pekarangan, tidak ada lagi area untuk kegiatan menghasilkan bahan pangan. Salah satu upaya silvikultur, yang dapat dilakukan untuk mengisi kesenjangan itu adalah pemanfaatan hidropopnik. pekarangan melalui konsep Rumah Pangan Lestari (RPL). Kegiatan pengabdian kepada masyarakat ini bertujuan untuk memasyarakatkan konsep RPL melalui beberapa kegiatan. Kegiatan pertama adalah sosialisasi dan penjelasan pentingnya RPL, dilaksanakan dengan metode ceramah dan diskusi dilanjutkan dengan demonstrasi pembuatan pupuk organik (MOL). Kegiatan berikutnya adalah pembuatan plot penanaman sayuran dan tanaman obat dengan metode silvikultur dan hidroponik. Kegiatan terakhir adalah penanaman bibit mangga. Semua kegiatan berjalan lancar dan mendapat sambutan positif dari masyarakat. Hal ini terbukti dari keikutseraan dan keseriusan para kader dan ibu-ibu rumah tangga dalam setiap kegiatan yang dilaksanakan. Diharapkan agar program RPL ini terus dikembangkan guna memenuhi kebutuhan sayuran maupun tanaman obat bagi keluarga yang dihasilkan di pekarangan sendiri.
\end{abstract}

Panduan sitasi / Citation guidance (APPA $7^{\text {th }}$ edition) :

Wiryawan, I. K. G., Rangga, D. A. R., Faruk, A., Ahmad, Aulia, A., Putra A. A., Akbar, D. S., Rahmatullah, M., Mutiara, Fitriani, R., \& Safinah, S. (2021). Optimalisasi Pemanfaatan Pekarangan Melalui Program Rumah Pangan Lestari Di Lingkungan Pejeruk Kota Mataram. Jurnal Abdi Insani Universitas Mataram, 8 (1), 65-71. http://doi.org/10.29303/abdiinsani.v8i1.383. 


\section{PENDAHULUAN}

Tersedianya bahan pangan merupakan salah satu kebutuhan untuk meningkatkan ekonomi dan ketahanan pangan bagi masyarakat. Tersediaan bahan pangan yang memadai baik dalam kualitas, kuantitas dan mutu gizinya, berpengaruh terhadap kualitas sumber daya manusia (SDM). Namun pertambahan jumlah penduduk dan perkembangan suatu kota atau kabupaten telah dan akan terus mengurangi area untuk kegiatan di bidang pertanian dalam rangka penyediaan pangan yang memadai (Tutuko, 2018). Permasalahan tersebut dapat ditemukan hampir di seluruh kota dan kabupaten di Indonesia, termasuk di Kota Mataram.

Sebagai contoh Kelurahan Pejeruk Kecamatan Ampenan di Kota Mataram. Dengan jumlah penduduk yang cukup besar, kepadatan Lingkungan Pejeruk semakin meningkat setiap tahunnya sehingga, Wilayah Pejeruk sudah dipenuhi dengan rumah-rumah warga. Hal ini menyebabkan tidak adanya lahan kosong yang dapat dimanfaatkan untuk penanaman sayuran maupun tanaman obat atau rempah sebagai sebagai pendukung ketahanan pangan masyarakatnya. Disamping itu, kelurahan yang sebagian besar penduduknya bekerja dibidang perdagangan dan jasa, dimasa pandemic covid19 ini masyarakatnya, terutama para ibu tidak melakukan aktivitas di luar rumah. Kondisi ini perlu diberdayakan untuk mengurangi kejen uhan.

Salah satu solusi untuk mengatasi permasalahan tersebut ialah adanya program optimalisasi pemanfaatan pekarangan yang di cetuskan oleh Kementrian Pertanian melalui konsep Rumah Pangan Lestari (RPL). Rumah Pangan Lestari (RPL) adalah rumah penduduk yang memanfaatkan pekarangan secara intensif dengan berbagai sumberdaya lokal secara bijaksana yang menjamin kesinambungan penyediaan bahan pangan rumah tangga yang berkualitas dan beragam (Oka, 2016). Kegiatan dalam RPL merupakan Aktivitas optimalisasi pemanfaatan pekarangan sebagai pendukung penyediaan sumber pangan dan perbaikan gizi rumah tangga.

Didasarkan atas keinginan untuk berpartisipasi dalam memasyarakatkan program RPL, Tim pengabdian kepada masyarakat Universitas Mataram Era new Normal memilih Lingkungan Pejeruk Abiyan di Kelurahan Pejeruk, sebagai lokasi untuk melaksanakan beberapa kegiatan seperti pembuatan pupuk organic MOL, memperkenalkan Teknik budidaya tanaman hidroponik, dan silvikultur. Uraian yang rinci dari kegiatan-kegiatan tersebut diuraikan pada bagian selanjutnya. Tujuan kegiatan pengabdian kepada masyarakat ini adalah optimalisasi pemanfaatan pekarangan sebagai penunjang kebutuhan pangan keluarga di Kelurahan Pejeruk. Optimalisasi pemanfaatan lahan pekarangan ini diharapkan dapat memberikan konstribusi dalam menghasilkan bahan pangan penunjang kebutuhan rumah tangga. Dengan beragamnya budidaya di pekarangan diharapkan rumah tangga tersebut akan mengkonsumsi beragam bahan pangan yang dihasilkan tanpa harus membelinya yang selanjutnya akan meningkatkan mutu gizi yang dikonsumsi (Purwantini, 2012).

\section{METODE PELAKSANAAN}

\section{Tahapan Kegiatan}

Tahapan pelaksanaan pemasyarakatan program RPL dalam rangka optimalisasi pemanfaatan pekarangan adalah sebagai berikut.

1. Sosialisasi kegiatan dengan Teknik ceramah dan tanya jawab. Materi yang disampaikan meliputi pembuatan pupuk organic dan budidaya sayuran dengan Teknik vertikultur.

2. Demonstrasi plot;

a. pembuatan pupuk MOL melibatkan para kader dilingkungan Pejeruk Abiyan dalam menyiapkan bahan dan proses pembuatan pupuk organik ini.

b. Vertikultur sayuran sebagai upaya memanfaatkan lahan pekarangan seoptimal mungkin

c. Penanaman pakcoy secara hidroponik sebagai contoh/alternatif menghasilkan sayuran tanpa menggunakan media tanah

\section{Alat dan Bahan}

Alat yang digunakan da lam melaksanakan program RPL adalah palu, gergaji, parang, cepang, 
paku, dan kawat. Sedangkan bahan yang digunakan adalah bambu, jaring hitam, polibag, dan botol bekas, dan sterofoam.

\section{HASIL DAN PEMBAHASAN}

\section{A. Sosialisasi program kerja}

Kegiatan pertama yang dilakukan adalah sosialisasi Program kerja. Kegiatan ini dihadiri oleh para Ketua RT dan para kader dari semua RT di Lingkungan Pejeruk Abiyan (Gambar 1). Kehadiran Tim pelaksana kegiatan pengabdian kepada masyarakat dan program yang ditawarkan untuk kelurahan Pejeruk, khususnya Lingkungan Pejeruk Abiyan disambut dengan antusias oleh mereka. Beberapa pertanyaan yang diajukan oleh para ibu saat diskusi berkisar pada jenis TOGA (Tanaman Obat untuk Keluarga), Khasiata tanaman dan cara mengolah TOGA, serta teknik dan bahan yang diperlukan dalam kegiatan RPL. Kegiatan-kegiatan yang melibatkan masyarakat dalam hal ini selalu menerapkan protocol pencegahan covid-19.

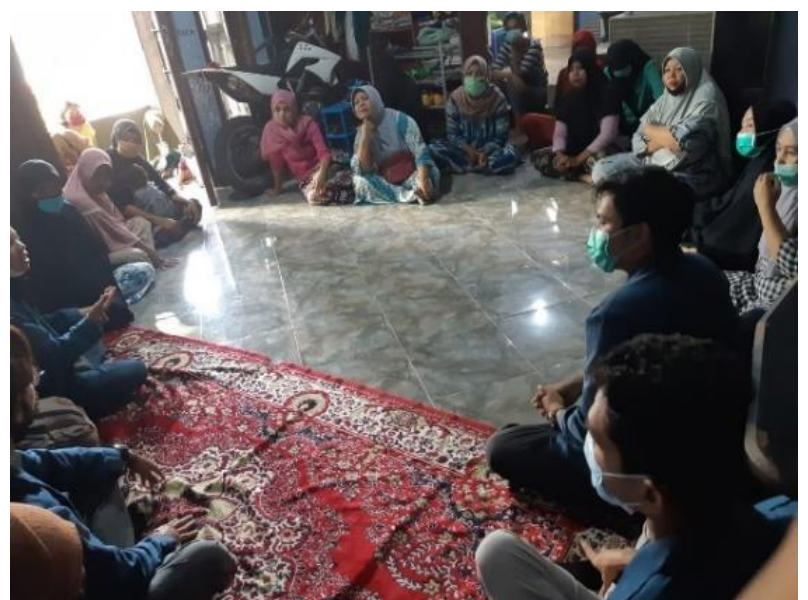

Gambar 1. Sosialisasi Program Kerja Bersama Warga Lingkungan Pejeruk Abiyan

Untuk lebih memantapkan pemahaman masyarakat akan pentingnya program RPL bagi lingkungan padat penduduk, Tim pelaksana kegiatan mendatangkan Penyuluh Pertanian yang bertugas di Kecamatan Ampenan yaitu Ibu Sri Mulyani, SP.

Sosialisasi dilakukan bersama warga masyarakat lingkungan Pejeruk Abiyan yang dihadiri oleh Kepala lingkungan, Ketua-Ketua RT dan para Ibu rumah tangga dan para Kader di lingkungan ini (Gambar 2). Materi yang disampaikan berkisar pada cara budidaya tumbuhan sayuran dan TOGA. Sebagai tambahan, kami mengingatkan kepada masyarakat untuk selalu mematuhi protokol Kesehatan yaitu menggunakan masker dan menjaga jarak agar terhindar dari penularan virus Covid19.

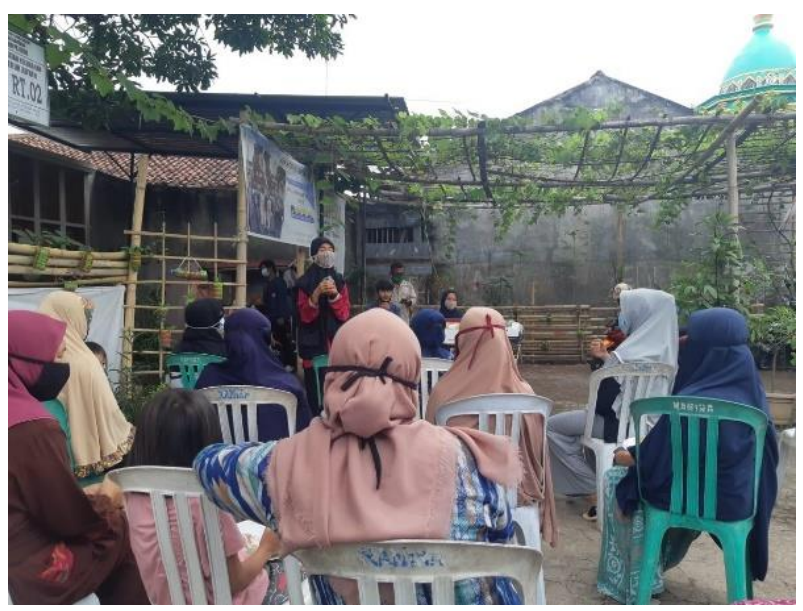

Gambar 2. Kegiatan sosialisasi program RPL. 


\section{B. Pelaksanaan Program RPL}

Kegiatan ini dimulai dengan pelaksanaan survey lokasi. Dari hasil survey dan diskusi bersama para Ketua RT ditetapkan bahwa lokasi kegiatan RPL berada disekitar pemukiman masyarakat yaitu di RT 01, RT 02 dan RT 05.

Prosedur kerja pelaksanaan program RPL adalah sebagai berikut.

1). Mempersiapkan alat dan bahan.

2). Menyiapkan tanah, polibag dan botol bekas.

3). Memasukkan tanah kedalam polibag dan botol bekas.

4). Menanam sayuran di polibag dan botol bekas,

5). Memasang media tanam dengan metode vertikultur.

6). Pembuatan pupuk organic (MOL).

7). Menyiapkan media untuk budidaya sayuran dengan metode hidroponik dan persiapan bibit tanaman TOGA.

8). Menyiram tanaman setiap hari.

\section{Kegiatan kedua adalah pembuatan pupuk organik.}

Pupuk organik adalah pupuk yang sebagian besar atau seluruhnya terdiri atas bahan organik yang berasal dari tanaman dan atau hewan yang telah melalui proses rekayasa melibatkan mikroorganisme lokal (MOL). Pupuk ini dapat berbentuk padat atau cair bermanfaat untuk memperbaiki sifat fisik, kimia, dan biologi tanah. Dibandingkan dengan pupuk kimia, pupuk organik disamping mengandung unsur mikro yang lebih lengkap, pupuk ini juga mempunyai kemampuan dalam memobilisasi atau menjembatani hara yang ada di tanah sehingga akan membentuk partikel ion yang mudah diserap oleh tanaman.

Kegiatan pembuatan pupuk organik $\mathrm{MOL}$ diikuti oleh para kader dan beberapa remaja yang sangat antosias (Gambar 3). Bahan-bahan yang gunakan diantaranya limbah buah-buahan seperti nanas, jeruk, air beras, gula merah. Kemudian alat-alat yang digunakan diantaranya seperti ember, selang, botol plastik dan cutter. Cara pembuatan dari pupuk ini yaitu memasukkan seluruh bahan ke dalam ember lalu diperas sampai sari-sari buahnya keluar, kemudian tambahkan air gula dan air beras sampai ember terisi $3 / 4$ nya. Selanjutnya ditutup rapat-rapat ember yang berisi bahan tersebut dengan menambahkan pada tutupnya yaitu selang dan dimasukkan ke dalam botol plastik berisi air sebagai sirkulasi udara agar memudahkan untuk membuka tutup embernya setiap hari.

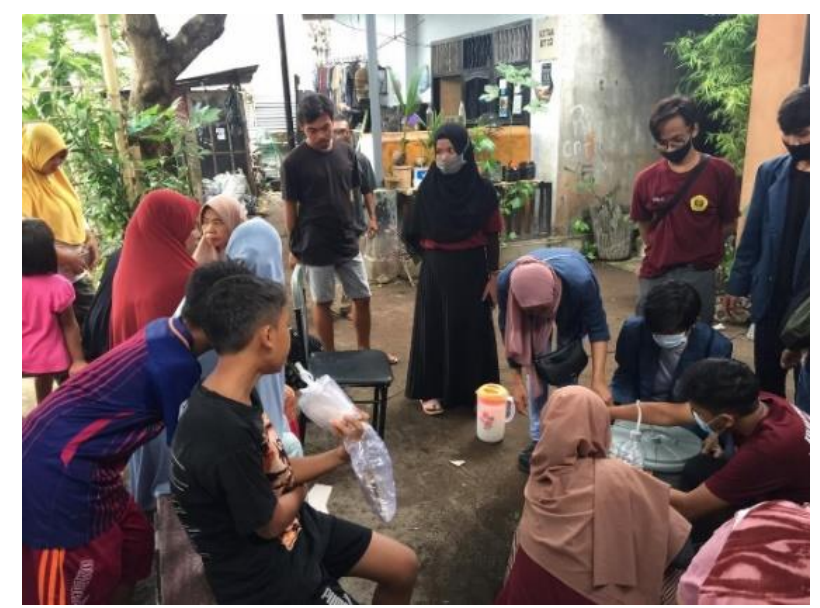

Gambar 3. Demonstrasi pembuatan MOL

Setelah itu diamkan selama 2 minggu agar terjadi fermentasi dan menjadi pupuk organik. Kegiatan ini berhasil baik ditandai dengan bau fermentasi seperti bau tape dan tidak berbau busuk. Pupuk organik yang telah jadi dibagikan ke masyarakat Lingkungan Pejeruk Abiyan. Diharapkan masyarakat dapat membuat sendiri pupuknya di kemudian hari untuk mengurangi biaya produksi. 


\section{Kegiatan ketiga adalah budidaya sayuran dengan teknik vertikultur.}

Lahan pekarangan berpotensi menyediakan bahan pangan untuk mengurangi pengeluaran rumah tangga jika dikelola dengan metode vertikultur. Vertikultur adalah suatu metode penanaman vertical atau bertingkat sehingga dapat menanam banyak tanaman di area yang sempit (Hidayati et al, 2018). Bahkan metode budidaya ini dapat dilakukan di rumah yang tidak memiliki halaman.

Media botol plastik digunakan untuk metode penanaman sayuran secara vertikultur (Gambar 4), sedangkan untuk metode hidroponik digunakan sterofoam (Gambar 5).

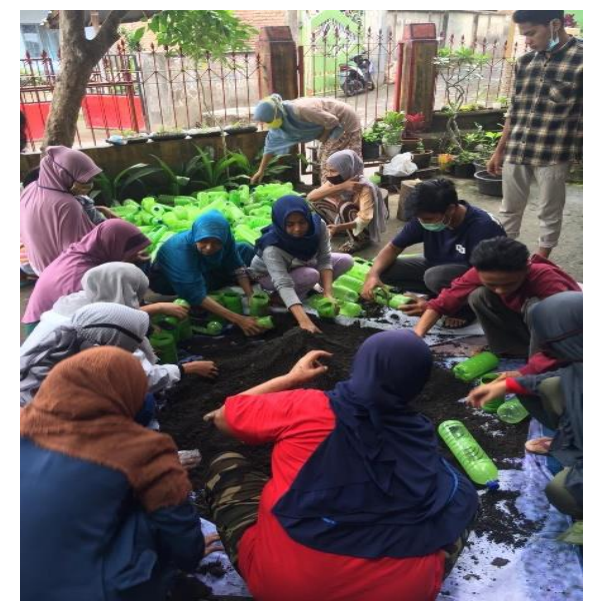

Gambar 4. Kegiatan memasukkan tanah dan menanam sayur-sayuran di botol plastic

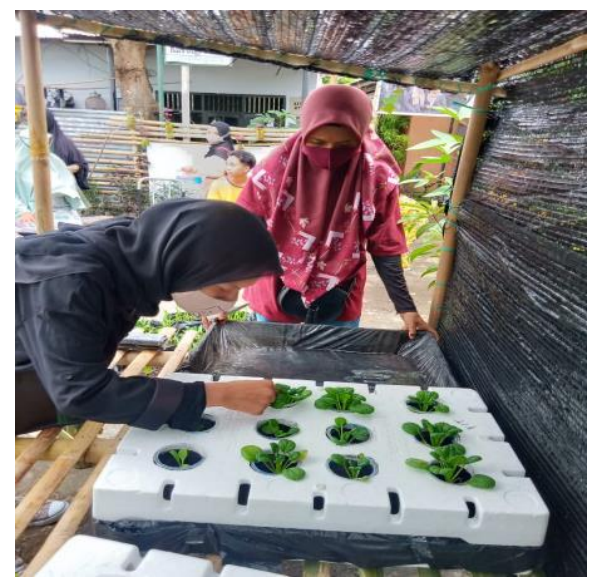

Gambar 5. Penanaman pakcoy secara hidroponik dengan media sterofoam

Sayuran yang ditanam diantaranya adalah tanaman kangkung, pakcoy/sawi hijau dan bayam.

Untuk tanaman TOGA Tim pelaksana kegiatan kepada masyarakat bersama ibu-ibu rumah tangga menanamnya menggunakan polybag (Gambar 6). Diakhir kegiatan ini Tim membagikan 40 bibit TOGA kepada perwakilan RT yang hadir. Pemupukan semua jenis tanaman menggunakan pupuk organic MOL, kecuali tanaman hidroponik. 


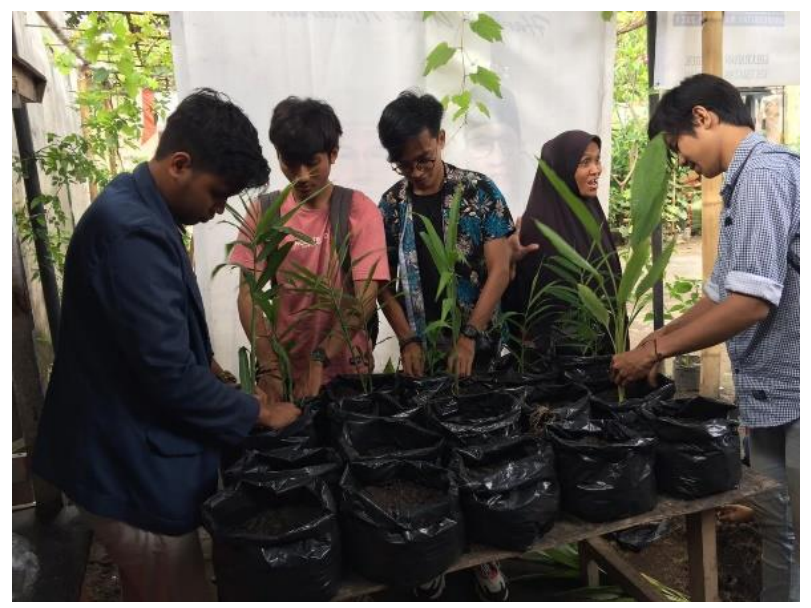

Gambar 6. Penanaman bersama warga bibit tanaman TOGA

\section{Kegiatan terakhir adalah penanaman bibit mangga}

Tanaman manga disamping Menghasilkan buah sebagai sumber vitamin dan mineral, juga dapat berfungsi sebagai tumbuhan untuk penghijauan. Bibit yang ditanam yaitu bibit pohon manga, pemberian dari Balai Benih Induk pertanian (BBI) yang berada di Kecamatan Narmada. Penyerahan bibit dilakukan secara simbolis di Kantor Kelurahan Pejeruk dan kemudian dibagikan kepada para Kepala Lingkungan (Gambar 7) yang untuk selanjutnya diteruskan kepada anggota masyarakat yang dapat menanamnya di pekarangan rumahnya. Penghijauan dilakukan di lima lingkungan yaitu Lingkungan Pejeruk Abiyan, Lingkungan Pejeruk Bangket, Lingkungan Kebun Bawak, Lingkungan Kebun Jeruk dan Lingkungan Pejeruk Perluasan. Diharapkan dalam 3-4 tahyun mendatang kelurahan Pejeruk menjadi lebih hijau dan lebih sejuk, disamping perbaikan gizi bagi masyarakatnya.

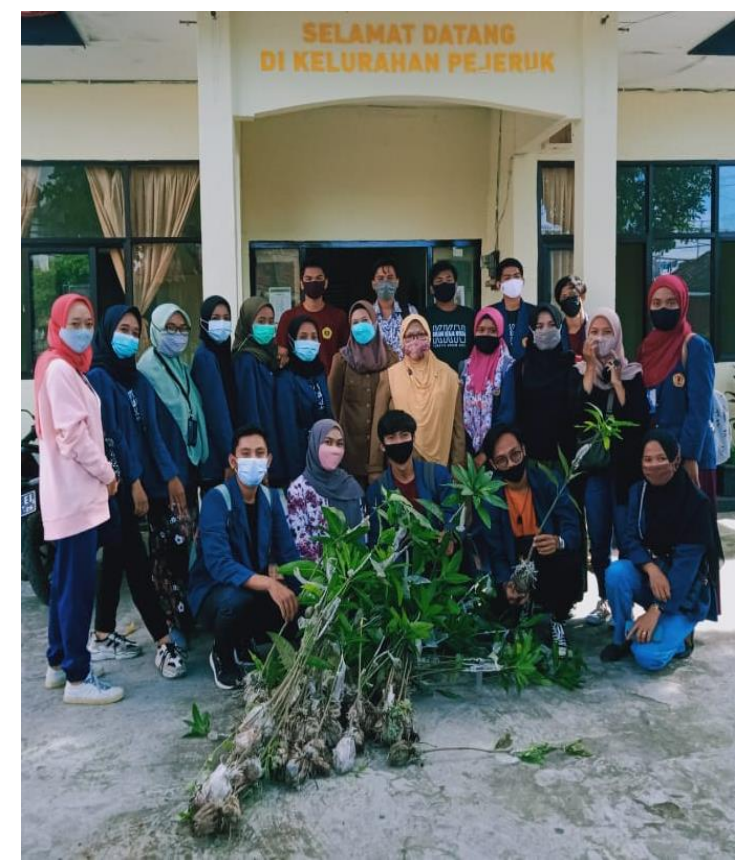

Gambar 7. Penyerahan Bibit Tanaman Mangga Di Kantor Kelurahan Pejeruk

\section{Monitoring dan Evaluasi}

Monitoring dan evaluasi kontinu dilakukan bersamaan dengan pedampingan masyarakat Lingkungan Pejeruk Abiyan dalam melanjutkan program kerja. Evaluasi program secara umum menunjukan bahwa masyarakat Lingkungan Pejeruk Abiyan Kelurahan Pejeruk berkomitmen memanfatkan dan mengelola rumah pangan lestari yang dibuat untuk keperluan pangan sehari-hari. 


\section{KESIMPULAN DAN SARAN}

Kegiatan untuk mewujudkan RPL di Lingkungan Pejeruk Abiyan, Kelurahan Pejeruk Kecamatan Ampenan Kota Mataram yaitu; penyuluhan tentang optimalisasi pemanfaatan penkarangan sebagai sumber pangan, pembuatan pupuk organik, plot penanaman sayuran dan tanaman obat dengan ketode silvikultur dan hidroponik, dan penghijauan. Semua kegiatan berjalan lancar dan mendapat sambutan positif dari masyarakat. Hal ini terbukti dari keikutseraan para kader dari setiap RT dan ibu-ibu rumah tangga dalam setiap kegiatan yang dilaksanakan. Diharapkan agar program RPL ini terus dikembangkan guna memenuhi kebutuhan sayuran maupun tanaman obat yang dihasilkan di pekarangan sendiri.

\section{UCAPAN TERIMA KASIH}

Tim pelaksana kegiatan pengabdian kepada masyarakat Universitas Mataram menghaturkan terima kasih Lurah, Kepala Lingkungan Pejeruk Abiyan, para Kader dan ketua RT yang telah mendukug dan bekerjasama dalam merintis terwujudnya Rumah Pangan Lestari (RPL). Ucapan terima kasih juga kami sampaikan kepada Balai Benih Induk Pertanian Narmada yang telah memberikan bantuan bibit pohon mangga, Ibu Sri Mulyani, SP. yang telah dengan sukarela dan penuh semangat membagikan ilmu dan ketrampilannya kepada ibu-ibu dan para kader di lingkungan Pejeruk Abiyan.

\section{DAFTAR PUSTAKA}

Hidayati, N., Rosawanti, P., Arfianto, F., \& Hanafi, N. (2018). Pemanfaatan Lahan Sempit untuk Budidaya sayuran sengan system Vertikultur. PengabdianMu 3(1): 40-46.

Kurniawan, Y.Y., Daerobi, A., Sarosa, B \& Pratama, Y.P. (2018). Analisis Program Kawasan Rumah Pangan Lestari Dan Hubungannya Dengan Ketahanan Pangan Serta Kesejahteraan Rumah Tangga (Studi Kasus Di Kota Surakarta). Jurnal IImu Ekonomi Terapan. Vol. 3 No. 2 p. 1-22.

Lukman, L. (2014) . Teknologi Budidaya Tanaman Sayuran Secara Vertikultur. www.litbang.pertanian. go.id/info-aktual/918/file/verikultur.pdf. dikases 9 Maret 2021.

Oka, G.A.D.S., Darmawan, D.P \& Astiti, N.W. (2016). Keberhasilan Program Kawasan Rumah Pangan Lestari (KRPL) pada Kelompok Wanita Tani di Kabupaten Gianyar. Jurnal Manajemen Agribisnis. Vol. 4 No. 2 p. 133-146.

Purwantini, T.B., Saptana \& Suharyono, S. (2012). Program Kawasan Rumah Pangan Lestari (KPRL) di Kabupaten Pacitan: Analisis Dampak dan Antisipasi Ke Depan. Analisis Kebijakan Pertanian. Vol. 10 No. 3 p. 239-256.

Saliem, H.P. (2015). Kawasan Rumah Pangan Lestari (KRPL): Sebagai Solusi Pemantapan Ketahanan Pangan. Jakarta: Kongres IImu Pengetahuan Nasional (KIPNAS). 